\title{
A Career in Patent Law: At the Cutting Edge of Science, but Not at the Bench
}

\author{
Salim Mamajiwalla \\ In(sci)te IP Patent Agency, Markham, Ontario L3S 4K5, Canada \\ Correspondence: salimm@insciteip.com
}

\begin{abstract}
Patent law is an area that many people move into after obtaining a PhD in biomedical science. Close to the cutting edge of research, patent agents draft detailed descriptions of new biotechnology inventions required for patent applications and engage with patent offices during the review process known as patent prosecution. Jobs are also available as patent examiners who examine these patent applications, and it is common for individuals to move between the two jobs. A law firm is generally the best place to train as a patent agent, but biotech companies and tech-transfer offices can provide an alternative route. Although obtaining a law degree is not essential after your $\mathrm{PhD}$, it is recommended, and all patent agents must pass rigorous qualifying exams. Further down the road, training in patent law offers opportunities for in-house work in biotech companies, business development, and mergers and acquisitions.
\end{abstract}

\section{WHAT IS INTELLECTUAL PROPERTY?}

ntellectual property (IP) is an umbrella term relating to creations of the mind. Unlike real property, IP is intangible. It is "intellectual" because it is derived from the work of the intellect. It is "property" because it has value and can be sold, bought, licensed, transferred, or given away like any other property. Governments have recognized the value of IP for enhancing their economies and have created laws for conferring IP rights (IPRs) to those individuals/corporations that develop certain IP in exchange for a full public disclosure of their invention. The rights conferred primarily allow the owner of the IP to exclude others from using their IP for a limited time. This creates a situation in which a competitor who wants to use the IP has to either innovate and design around the existing IP, buy it, or rent (license) it. IP owners may sue those infringing on their IPRs.
There are several forms of IPRs. The most common include patents, trademarks, trade secrets, industrial designs, and copyrights. To a knowledge-based company, such as a biotech company, the most important and valuable IPRs are patents, know-how, and trade secrets.

A patent is a time-limited monopoly (normally 20 years from the date of filing a patent application) granted by a government to the inventor or the owner of the patent in exchange for full disclosure of the invention to the public. The exclusive right granted to the patentee allows him/her to exclude others from making, using, selling, or distributing the patented invention without permission, that is, without a license. It does not give the owner of the patent the right to make, use, sell, or distribute his/her own invention unless he/she has in turn determined that there are no earlier patents excluding him/her from performing any one or more of these activities.

Editors: Kaaren Janssen and Richard Sever

Additional Perspectives on Career Options for Biomedical Scientists available at www.cshperspectives.org

Copyright (C) 2018 Cold Spring Harbor Laboratory Press; all rights reserved

Cite this article as Cold Spring Harb Perspect Biol 10: a032920 
Obtaining a patent can be a long, arduous, and expensive process. This is especially true for life-science-related inventions because the technology involved is often complex. Obtaining a patent begins with the preparation of the patent application. The application must be carefully drafted after having considered a multitude of factors, including the prior art, ${ }^{1}$ the patent laws (which may differ from country to country), and the latest court decisions. Ideally, a patent application should have an abstract, a background, a summary of the invention, a detailed description of the invention, and examples of how to make and use the invention and must end with at least one claim. ${ }^{2}$ Drawings or figures are also often provided and described, if they can aid in understanding the invention or further support the examples. The all-important claims must be carefully crafted to define the invention in words, which must also be carefully chosen. Although patent laws vary from country to country, it is universally accepted that to be patentable, the claimed invention must be novel and nonobvious to someone skilled in the art to which the subject matter of the patent application relates, and have some utility, that is, real-world use. Various other requirements must also be met. For example, a patent application must be drafted to satisfy the written requirements for patentability and define and enable the scope of the claimed invention.

Once the application is drafted to the satisfaction of the client, it is usually first filed with the Patent and Trademark Office (PTO) in the inventor's respective country, although many foreign inventions are often first filed in the United States PTO. The application is then examined by a patent examiner, who will most likely have academic qualifications similar to the patent lawyer. The examiner will review the application in light of the prior art and the

\footnotetext{
${ }^{1}$ Prior art is a term used in patent law to describe all patent and nonpatent literature (e.g., journal articles, abstracts for conferences) related to the subject matter of the invention published before the earliest filing date of the patent application.

${ }^{2}$ Claims are the most important part of the patent. The claims point out and distinctly delineate in words the subject matter that the inventor regards to be his or her invention.
}

patent rules and laws for that country. The examiner will then either allow the patent or, more often than not, issue a rejection of the patent along with a detailed explanation as to their reasoning. This reasoning is often a combination of legal and scientific arguments. The applicant is given the opportunity to respond to the examiner's rejection by amending any defects and arguing against the examiner's rejection. This back-and-forth exchange of arguments with the PTO is referred to as patent prosecution and in some instances can take many years before the application is in condition for the PTO to issue what is called a Notice of Allowance, a formal notice by the PTO that it has agreed that the invention as claimed is patentable and that the application will proceed in due course to a granted patent. ${ }^{3}$

\section{JOBS}

Jobs as a patent professional can be very competitive and there are only a limited number of places at which one can work as a patent agent. Law firms with IP departments will often hire $\mathrm{PhDs}$ to train and ultimately qualify as patent agents; these individuals work side by side with lawyers, paralegals, and other IP support staff. Alternatively, if you are currently a scientist in a biotech, pharmaceutical, or other life-sciencerelated company with a sizable IP department, you might be able to start training there. Patent offices also hire PhDs to train as patent examiners. Finally, if you are at an academic institution, the tech-transfer office can be a good place to start.

\section{Law Firms}

A law firm is probably the best place to train to become a patent agent because you will gain valuable training and experience in IP law through exposure to a broad variety of issues in patent law. Law firms generally hire $\mathrm{PhDs}$ as "patent specialists," "scientific/technical

${ }^{3}$ It is not unheard of to have applications pending in the PTO for 5 or more years. 
advisors," or "patent agent trainees." These titles are synonymous. Firms with large IP practices or large boutique IP firms may be divided into different practice areas by subject area groups, for example, life sciences/chemistry, mechanical, or high tech, and you will most likely be placed in a group that matches your educational background. Patent specialists are usually placed under the supervision of a senior associate or a partner.

Law firms tend to have a diversified clientele and hence you will be exposed to a variety of different inventions. Thus, if you are a life scientist, you may get to work on a new drug molecule for the treatment of a particular disease, novel drug delivery systems, antibodies, genetically modified organisms, processes for purifying or isolating compounds, or, at times, even medical devices. It is not uncommon for law firms to have new hires start by drafting mechanical inventions regardless of educational background; only once the trainee becomes familiar with the fundamentals of drafting and the law will they assign you cases related to your technical specialty. With more experience, you may be pulled into other areas of IP law that require a sophisticated understanding of the underlying technologies, including assisting in due diligence, mergers and acquisitions, or litigation. When working for pharmaceutical clients, you will also likely develop a working knowledge of how regulatory law intersects with IP law and how you might be able to leverage both to obtain maximum protection for the company's innovative drugs or medical devices.

A word of caution: The law firm environment is not for everyone. The concept of the "billable hour," in which every minute of the working day must be accounted for, is foreign to scientists and can be difficult to get used to. Law firms generally set an annual "billable target" for every professional to strive to meet, and the target is dependent on many things, including, for example, your position within the firm, its size, and its geographical location. Your performance review, and hence bonus and promotion, can depend, in part, on whether you met your billable target for the previous year. Although individual experiences vary, it is not uncommon in large law firms with busy patent departments to place high demands on patent specialists. You might work 6 to 7 days a week in the beginning (which you should be used to as a postdoc). Your hours will be long (again, nothing new), and expect a portion of your hours to be written down as you learn to apply your newly acquired patent skills. Nevertheless, the training you will receive at a law firm will put you on firm footing for future positions elsewhere. For example, biotech/pharmaceutical companies, although they usually prefer to hire patent agents/lawyers who already have corporate experience, will also recruit from law firms. ${ }^{4}$

\section{Biotech/Pharmaceutical Company}

If you are a staff scientist at a biotech or pharmaceutical company with a sizable patent department, you may be able to transition into IP law by training under the supervision of a company patent agent/lawyer. Alternatively, as mentioned above, you may transition into a biotech/pharmaceutical company after having gained several years experience in a law firm. Depending on the focus of the company, you may not be exposed to the broad variety of issues you might see at a law firm. Nevertheless, working in a corporate setting can be quite rewarding. You will have the opportunity to interact with various other departments within the company, such as research and development (R\&D), marketing, regulatory affairs, clinical operations, and finance, and see how the IP you are working on fits into the overall business strategy for a particular product. It is rare that you get to gain this same intimate knowledge of the overall strategy when working externally in a law firm representing the client than when working in-house. You will likely have to formulate the optimal IP strategy based on the marketing and/or regulatory strategy for a particular product, which may not always involve procuring a patent, and provide your rationale

${ }^{4}$ Corporate positions are often referred to as in-house positions. 
in support of this strategy to the product team and management. You will be faced with problems that require unique solutions. Finally, you will continue to build on your patent experience and gain a unique perspective about the biotech/pharmaceutical business.

\section{Patent Offices}

The primary function of a country's PTO is to enable the protection of IP, including the granting of patents to those deserving of that protection in accordance with the relevant laws of that country. To fulfill this function, at least where patents are concerned, the PTO hires individuals with the relevant academic background to examine patent applications. Examiners are trained to assess the patentability of the inventions in accordance with their country's law. Given the highly technical nature of chemical inventions, which include biotech/ pharmaceutical inventions, the PTO hires individuals with doctoral training in the relevant scientific disciplines. The one important distinction between examiners and agents is that examiners are not trained to draft patent applications. It is not uncommon for examiners to move into law firms once they gain sufficient experience at the PTO. Having once worked as an examiner gives them the added advantage of knowing the inner workings of the PTO, including what the PTO will be looking for when examining an application.

\section{Tech-Transfer Offices}

Tech-transfer offices are dedicated to identifying technologies developed within academic institutions that have promising potential for commercialization. Once identified, patent protection is usually sought for the practical use of the technology. Large tech-transfer offices may have their own internal patent agents/lawyers, but more often than not, they outsource the drafting and prosecution of the patent application to outside patent firms. Nevertheless, techtransfer offices provide a good place to learn about the patent process and can be a good springboard for applying for a job as a patent agent trainee at a law firm.

\section{SKILLS AND QUALIFICATIONS REQUIRED FOR AND GAINED DURING TRAINING AS A PATENT AGENT/LAWYER}

What academic qualifications do you need to transition into patent law? Must you have a PhD? Do you need to spend another 3 to 4 years getting a law degree? Do you have to be certified/registered to practice patent law?

Patent practice is unique in that it is the only branch of law where a law degree is not required to practice. Nonlawyer patent professionals do have significant limitations in terms of what they are qualified and licensed to do, however. For example, as a registered United States or Canadian patent agent, you are not permitted to advise a client regarding issues dealing with patent validity, infringement, or litigation. In the United States and Canada, you certainly cannot represent a client in court, even on patent-related issues. Many jurisdictions do not permit nonlawyer patent agents to enter into legal partnerships with lawyers, regardless of the number of years that they have been at the firm, the number of clients that they have, or the amount of billable hours that they have docketed. $^{5}$

A $\mathrm{PhD}$ is not necessary either. In fact, you may transition into patent law with as little as a bachelor's degree in science (e.g., physics, engineering, math, chemistry, biochemistry, cell biology, genetics, biology). But a $\mathrm{PhD}$ is desirable, especially in the life sciences/chemistry, and the more technical expertise you have, the better. Most law firms looking to hire in the life sciences field will not consider applicants for a posi-

\footnotetext{
${ }^{5}$ Law professional bodies of certain countries, such as the United States, permit individuals to obtain a law degree on a part-time basis by going to law school at night. Some countries, on the other hand, require that you attend law school on a full-time basis. Given the limitations on nonlawyer patent professionals, and if time and resources and your personal circumstances permit, ultimately obtaining a law degree is becoming increasingly the norm for $\mathrm{PhD}$ scientists who enter the field of patent law, and is one I highly encourage. Many law firms, especially in the United States, may even foot the bill for you to attend law school.
} 
tion unless they have a $\mathrm{PhD}$. In other fields, such as mechanical or electrical engineering, a bachelor's degree may be sufficient. However, depending on the type and size of the law firm, a master's degree might be a minimum. At boutique IP firms, ${ }^{6}$ the majority of nonlawyer patent professionals will have a $\mathrm{PhD}$ and many of the lawyers will have, at minimum, a master's degree.

Regardless of whether or not you have a law degree, as a patent professional you must become registered/certified to practice patent law before the PTO of your country by passing a rigorous examination. Certain countries require that you have a minimum amount of on-the-job experience before you can sit for the exam. Once certified, you can file and prosecute patent applications on your own in the PTO of your country. Nonlawyer patent professionals, once they have passed the patent agent's exam, are often referred to as "patent agents" in the United States and Canada, or "patent attorneys" in the United Kingdom, Germany, and certain other jurisdictions.

Law firms, where you will most likely start your new career, look for individuals who are not only self-starters but can work and manage projects independently. The majority of your time will be spent drafting and prosecuting patent applications and communicating with your clients, examiners, and other officials at the PTO. Hence, you must be able to write and verbally communicate well. You must have excellent time management skills and work under pressure because there will be times when you will have to draft patent applications or respond to correspondence from the PTO on short notice. You must be able to quickly make sense of complex data given to you by your clients, and

\footnotetext{
${ }^{6}$ Boutique IP firms are those that only practice IP law, including IP-related litigation. General-purpose law firms, or full-service law firms as they are sometimes called, are those that practice other areas of law in addition to IP law, such as corporate, real estate, criminal, or employment law. There are even smaller boutique IP firms that specialize in only life science IP or high-tech IP. Such firms are normally run by solo practitioners or groups of two or three professionals. It is unlikely that such small firms will take on nonlawyer PhDs as trainees.
}

you must be able to think logically and have strong reasoning skills. Based on the data provided to you by your client, you must be able to ask and answer key questions that will allow you to advocate for the patentability of your client's invention, or request more data from your clients to be able to further strengthen the argument for the patentability of their invention. You will be required to come up with creative solutions to difficult problems. Now, think about it-don't you already have the skills highlighted above? These are skills that you started acquiring as a graduate student when you worked under the guidance of your $\mathrm{PhD}$ supervisor, and you likely perfected them as a postdoc when you worked independently in another principal investigator's laboratory.

You will also learn new skills and build on those you already have. Initially, you will find drafting a patent application, especially the claims, an exercise in pure frustration (much like writing your first grant). Drafting a patent application is part art, part science. There are plenty of texts out there that will teach you how to draft a patent application and the accompanying claims, but none of these will replace onthe-job experience. Be patient, and be prepared to have your drafts come back with a lot of red ink. Just as it took you time to develop and perfect the techniques that you learned at the bench, it can take many years before you are comfortable drafting and prosecuting patent applications without a second set of eyes looking over your work. You will also learn how to be nonconfrontational and try to understand the other person's point of view and how to give in on issues of less importance. You will likely learn aspects of IP licensing agreements and issues relating to IP when companies merge or are acquired. With those cases, you will learn how to work with a team of lawyers from different areas of law and see how IP fits into the big picture.

\section{GETTING A FOOT IN THE DOOR}

How do you market yourself for the transition to patent law? You need to reinvent yourself. The first place to start is your resume. Scientists tend 
to have a voluminous curriculum vitae identifying every publication, every conference at which they presented, and every poster submission. These achievements are important because they demonstrate your writing, speaking, and presentation skills, but for your new job applications these areas should be toned down. Instead, you need to highlight the skills described above-the more generic analysis, reasoning, and creative thinking skills that are transferrable and will make you marketable as a patent agent trainee or technical advisor. Highlight any other experience you may have had with patents or the patent application process. For example, you might have been fortunate enough to have your name listed as an inventor on one or more patents or patent applications while you were at the bench. Make sure to make a point of this. It will demonstrate, at the very least, that you are familiar with the patent process.

Next, flood law firms, universities, and biotech/pharmaceutical companies in your area, or the city to which you are relocating, with your new resume. If possible, become a member and attend the local IP association meetings. ${ }^{7}$ If you are at an academic institution, contact the law school career services office for opportunities to transition into IP law or set up a meeting with a career guidance counselor.

Finally, and perhaps most importantly, network, network, network. Although there are many social and professional networking sites where you can post your new resume and announce that you are looking to transition into IP law online, nothing will replace the old-fash-

\footnotetext{
${ }^{7}$ Many cities have IP associations that organize events, usually held monthly, primarily for the benefit of the local business community. These "breakfast" or "lunch and learn" meetings are held to educate local businesses on basic issues related to IP law and the best practices for managing their patent portfolio. These events are also meant to keep businesses up to date on important issues raised by court decisions that may impact their patent strategy. Certain law firms also organize seminars that are open to the public on hot-button IP topics. Such events are good networking opportunities to meet with a wide variety of IP professionals and business leaders. Find these events by searching for them on the Internet or inquire at the law department of your academic institution.
}

ioned in-person meeting. Call up a patent agent or lawyer at a firm and offer to buy them coffee for a brief introduction and an "informational interview." Stress that you simply want to learn more about the profession. Once you are in conversation at the coffee shop, you can ask them to let you know if they hear about openings for a $\mathrm{PhD}$ with excellent skills such as yours. Call someone you may know who has made this transition into IP law. Ask them for advice and assistance.

Transitioning into IP law is not easy. It takes a lot of courage to step out of your comfort zone and start at the bottom of a new career that you know barely anything about. But you have the skills and most of the qualifications. The rest you will learn on the job. The road to success is filled with challenges. You have the courage and wherewithal to overcome these obstacles. After all, you could not have come this far if you had quit after the first failed experiment as a graduate student. Transitioning into IP law is no different. There will be many disappointments, but the key, as with any disappointment, is to learn and build on your experience. IP law is a challenging career, but it can also be a very rewarding one, both financially and intellectually. Persevere, and you will find that the light you see at the end of the tunnel will guide you to a very bright future where your skills and technical expertise are very much in demand.

\section{WAY OUT}

As you gain more experience in IP law, especially if you hold an in-house position, you will likely learn aspects of IP licensing and will also acquire experience related to IP issues associated with mergers and acquisitions. This knowledge, together with your science background and your IP experience, will provide you with a powerful skill set that can lead to other career opportunities in licensing and/or business development within your current organization outside of the legal department. You may, for example, be able to transition into the business development organization of the company that you work for and assist them in assessing the strength of the 


\section{BOX 1. My Experience}

The opportunity to be a summer student in the Molecular and Cellular Physiology course at Woods Hole Marine Biological Laboratory while a graduate student at the University of Miami School of Medicine was a defining moment in my scientific career. Sixty of us were chosen out of 600 graduate students from all over the world who had applied for the course. It was a glorious summer, one I will never forget. I rubbed shoulders with some of the finest minds in cell and molecular biology. I was convinced, after that experience, that there was only one path to follow-the traditional academic track to having my own laboratory. I knew, even back then, that this was not going to be easy. There were already rumblings about how competitive it was going to be to get an academic position. But I believed that pedigree was an important factor and if I could postdoc at a world-renowned institution under the mentorship of a leading scientist in his/her field, I would have a leg up on the competition. I was next accepted for a postdoc at Cold Spring Harbor Laboratory, the Mecca for molecular and cellular biology. My project was to unravel the mysteries of a cell-surface receptor that had recently been cloned. We had a rough idea of what the receptor might do, but we had to prove it. I had to identify the ligands and/or substrates and elucidate the signal transduction pathway by which this receptor might exert its effects. Other postdocs had made significant progress in the same laboratory with other proteins in the family. All I had to do was follow the same strategy they used.

Fast-forward five years and I had yet to publish. The turning point came at a conference in Keystone. My laboratory colleagues and I were sitting in front of the fireplace while two laboratory mates discussed the day's presentations and how their work would tie in. Their excitement was palpable. I just could not get excited. I realized at that moment that I had lost my passion for bench work, but not science. My personal circumstances were also weighing on me. I had recently been married to a physician in Toronto, Canada. We had had a commuter marriage for the previous 3 years. One of us had to move, and given my circumstances, it only made sense that I move to Toronto. The decision to transition was a difficult one. I felt I had worked hard, perhaps for nothing. What could I possibly do with everything I had learned so far? After much research and networking, I came to know of a former Cold Spring Harbor postdoc who had made the transition into patent law and I decided to give her a call and ask for her advice. Obviously, it worked out well-very well.

I rewrote my resume and sent it out to every single law firm in Toronto. I was eventually offered a position as a patent agent trainee in the IP department of one of the biggest general-purpose law firms in the country. Six months into it, I knew that the law firm environment was not for me. Although I enjoyed patent law, I had decided that at some point I needed to work for a biotech/pharmaceutical company, that is, I needed to move in-house. That opportunity arrived eight years later, when I interviewed for a position to head up IP for Canada's largest publicly held pharmaceutical company, Biovail Corporation. In the meantime, I kept working at the law firm, not only learning as much as I could about IP law and honing my patent drafting and prosecution skills, but also networking, primarily with members of the biotech and pharmaceutical business community in and around Toronto. My mandate at Biovail was to build an IP department and be responsible for the company's global patent strategy. My primary responsibilities were to draft, prosecute, and maintain the IP related to the company's drug delivery technologies; assist R\&D to ensure that projects had the necessary data to support patentability of these projects; inform senior management of potential risks to the patent portfolio; and work together with individuals from other departments such as regulatory and marketing and provide them with scenarios for what would happen to the exclusivity for a particular product in the event that the patent(s) was challenged. I also assisted corporate lawyers in the legal department on IP clauses in agreements relating to the out-licensing of our products or in-licensing of products/ technologies. I started at Biovail as Manager, Patents and over the next nine years, I moved up the corporate ladder to Senior Manager, Director, and finally to Senior Director, Intellectual Property.

In September 2010, Biovail Corporation was purchased by Valeant Pharmaceuticals. The IP department was gradually dissolved and I was finally packaged-out in June 2011. I eventually came to the decision that it was time to go solo and set up my own patent agency. In(sci)te IP was 
S. Mamajiwalla

formed in June 2012, at which time I had zero clients. My first course of business was to network and convince start-up life science companies to sign me on as their patent agent. The networking took me halfway around the world to Malaysia (I am a Malaysian citizen and a Canadian permanent resident), where I knew that the government was actively funding R\&D in the life sciences, primarily in the herbal industry. I also believed that my experience in North America would be a significant advantage. After much networking I managed to sign on my first client and have since signed on several others. The networking, together with what I learned about the pharmaceutical business while at Biovail, however, has now led me to start up my own biotech company in Canada, but that is a story for another day. ${ }^{8}$

"'If you want to play a game, go to where it's played and find a way to get in. Things happen when you get in the game," Chris Matthews, Commencement Speech, Fordham University, May 20, 2006.

\section{BOX 2. Ten Dos and Don'ts}

1. Do read the patent blogs. These websites provide useful summaries of the latest developments in patent law and summarize important court decisions. Reading the patents that were key to the decisions helps in understanding how to, or not to, draft a patent application. The following blogs focus on biotech/pharma/life science IP law: http://www.patentdocs.org, http://www .patentbaristas.com, http://www.pharmapatentsblog.com, and http://www.patents4life.com. Another popular blog can be found at http://patentlyo.com.

2. Do not highlight your area of research. Your expertise in cell-cycle research, genomics, or cancer research is not of particular relevance, but do highlight your analytical and reasoning skills. These are the transferable and valuable skills.

3. Do network, network, and network. You will have to kiss a lot of frogs before you find the position that you want.

4. Do not stop networking even after you have transitioned into IP law. You never know what opportunities might come up.

5. Do learn how to read a patent. These can be found easily at https://www.google.com/?tbm=pts. Search by keyword and you will find a ton of documents. To begin, search for patent documents in your area of research.

6. Do seek out other PhDs who have made the transition into IP law and ask for their advice.

7. Do get to know IP support staff when you have found a patent agent trainee position. They have a wealth of information on IP rules and regulations.

8. Do not be a "know-it-all." Transition with an open mind. Be humble and willing to learn. You will have to learn a new language and a new way of thinking. You will have to start at the bottom, again.

9. Do be confident of your skills.

10. Do not let criticisms of your drafting get you down early on. After all, you are learning. Persevere and you will become good at your job. 
science and IP of a biotech company that is being considered as a target for acquisition or for licensing of their proprietary technology.

\section{ACKNOWLEDGMENTS}

I thank Lana Janes, Melanie P. Merriman, and Shaheen Doctor for their comments. Lana is a chemist who took a career path similar to mine and is now Vice President, Intellectual Property and Chief Patent Counsel at a biotechnology company in Vancouver, Canada. We were, and still are, each other's support system. Melanie was one of my $\mathrm{PhD}$ supervisors, and Shaheen, Medical Director of the Neonatal Intensive Care Unit at North York General Hospital in Toronto, is my wife and the reason that I moved to Toronto. 


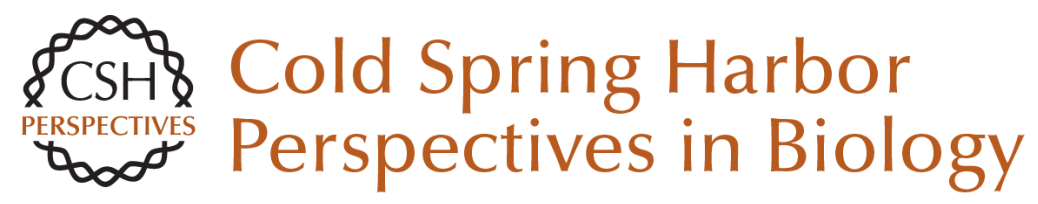

\section{A Career in Patent Law: At the Cutting Edge of Science, but Not at the Bench}

Salim Mamajiwalla

Cold Spring Harb Perspect Biol 2018; doi: 10.1101/cshperspect.a032920

Subject Collection Career Options for Biomedical Scientists

Careers in Science Publishing John R. Inglis

Medical Communications: The "Write" Career

Path for You?

Yfke Hager

At the Crossroads of Science and Society:

Careers in Science Policy

Amy P. Patterson, Mary E. Groesch, Allan C. Shipp, et al.

A Career in Patent Law: At the Cutting Edge of Science, but Not at the Bench Salim Mamajiwalla

Careers in Science and Grant Administration:

View from the National Institutes of Health Marion Zatz and Sherry Dupere

Careers at Biotech Start-Ups and in

Entrepreneurship

Susan Froshauer

Careers in Science Journalism and Writing Helen Pearson
Careers in Academic Administration Lydia Villa-Komaroff

Working for a Scientific Society Martin Frank

\author{
A Career for Life Scientists in Management \\ Consulting \\ Rodney W. Zemmel
}

Careers in Core Facility Management Claire M. Brown

Leaving the Bench and Finding Your Foundation John E. Spiro
A Career at a Small Liberal Arts College Jennifer Punt

Career Options for Scientists

Richard Sever and Kaaren Janssen

For additional articles in this collection, see http://cshperspectives.cshlp.org/cgi/collection/

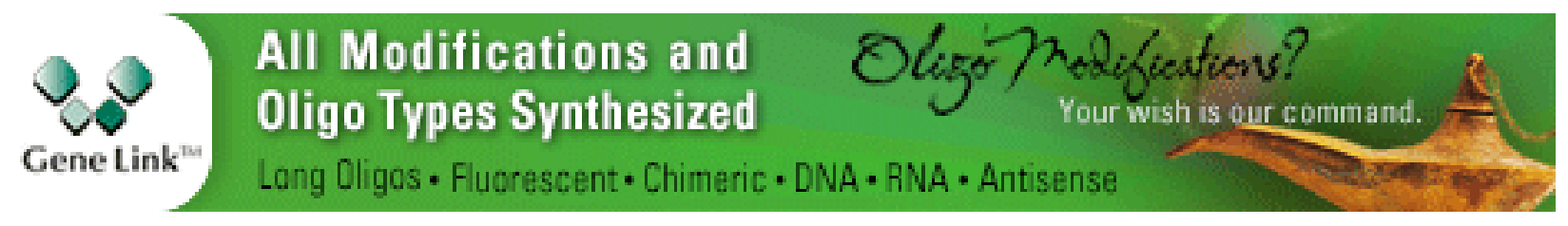

Copyright @ 2018 Cold Spring Harbor Laboratory Press; all rights reserved 